\title{
Design Theory for Screw Geometry in a Briquette Press
}

Miloš Matúš, L'ubomír Šooš, Peter Križan, Juraj Beniak, Juraj Ondruška

Faculty of Mechanical Engineering, Slovak University of Technology in Bratislava. Namestie slobody 17, Bratislava, 81231 Bratislava. Slovakia. E-mail: milos.matus@stuba.sk

This paper focuses on the structural design of screw tools in briquetting presses used for the production of solid, high quality, bio fuels. The primary objective is to analyse the screw tool geometry and determine a procedure for its design, specifically the theory involved with the pressing tool and force relations which are necessary for the verification of the proposed tool geometry and its strength analysis. In designing the main drive of the press, procedures for determining frictional performance of the screw press are used. Familiarity with the above mentioned procedures forms the basis for research into new tools in screw briquetting presses that will improve the service life and competitiveness of the technology.

Keywords: biomass, briquetting, tool, screw, screw profile

\section{Acknowledgement}

The research presented in this paper is an outcome of the project No. APVV-0857-12 "Tools durability research of progressive compacting machine design and development of adaptive control for compaction process" funded by the Slovak Research and Development Agency.

\section{References}

[1] MATÚŠ, M., KRIŽAN, P. (2010). Influence of structural parameters in compacting process on quality of biomass pressing. In: Aplimat - Journal of Applied Mathematics, Vol. 3, No. 3, pp. 87-96.

[2] BROŽEK, M. (2015). Briquettes Made from Wood Residues. In: Manufacturing Technology, Vol. 15, No. 2, pp. 126-130.

[3] MATÚŠ, M., KRIŽAN, P., ONDRUŠKA, J., ŠOOŠ, L. (2011). Analysis of tool geometry for screw extrusion machines. In: Proceedings of Aplimat 2011. pp. 415-425. FX s.r.o., Bratislava.

[4] TOMIS, F. (1975). Basics of Rubber and Plastics Technology. University of Technology in Brno. Publishing house VUTIUM, Brno. pp. 278.

[5] MATÚŠ, M., KRIŽAN, P. (2012). Modularity of Pressing Tools for Screw Press Production Solid Biofuels. In: Acta Polytechnica. Vol. 52, No. 3, pp. 71-76.

[6] LISÝ, M., BALÁŠ, M., ŠPILÁČEK, M., SKÁLA, Z. (2014). Technical and economic optimization of cogeneration technology using combustion and gasification. In: Acta Polytechnica, Vol. 54, No. 1, pp. 42-51.

[7] LEGUTKO, S., KROLCZYK, G., Krolczyk, J. (2014). Quality Evaluation of Surface Layer in Highly Accurate Manufacturing. In: Manufacturing Technology, Vol. 14, No. 1, pp. 50-56. 